\title{
Rabbit Protein Adsorption Properties of Copper (II) Ion-Polluted Soil
}

\author{
Yi Zhang*, Hao Zhang, Weizheng Yang \\ School of Textiles, Tianjin Polytechnic University, Tianjin, China \\ Received: March 30, 2015 \\ Accepted: May 26, 2015
}

\begin{abstract}
Soil polluted with heavy metal ions is a serious environmental problem. Rabbit protein, prepared by reduction method $\mathrm{C}$, had excellent adsorption performance of heavy metal ions. The adsorption mechanism of rabbit protein was studied and the adsorption process could be well described by the quasi-secondary dynamics equation. When the dosing quantity of rabbit protein powder was $50 \mathrm{~g} / 1$ and the adsorption time was $180 \mathrm{~min}$, the removal rate of $\mathrm{Cu}^{2+}$ reached $58.52 \%$. Combining the zeolite powder and using the principle of electro spinning, the nano protein membrane was prepared to adsorb copper ion in the soil, which was efficient, low-cost, and achieved excellent adsorption effect. Hence it could be used as a new type of adsorption material to work out the pollution of heavy metals in the soil. Using waste to treat waste not only realized the reasonable use of a natural protein resource, but also had a certain practical significance on the safety of green organic food.
\end{abstract}

Keywords: rabbit protein, electro spinning, adsorption mechanism, soil remediation

\section{Introduction}

As a natural resource for human survival, soil plays an important role on the ecological environment. The pollution of heavy metal ions in the soil is spreading from local to regional areas - even the whole world. Heavy metal pollution is detrimental to the environment immediately or potentially. The greatest threat is its degradation, which can exist in the environment for a long time, and migrate to all spheres of the earth's surface system [1, 2]. It can also enrich the human body through the food chain, and translate into metallo-organic compounds that have stronger toxicity $[3,4]$. Unlike water pollution and air pollution, soil pollution is hidden and unnoticeable, and just for this reason, people have not paid enough attention to it, which leads to a serious consequence. Until now, Chinese agricultural acreage polluted by heavy metals such as $\mathrm{Cu}, \mathrm{Pb}$, and $\mathrm{Cr}$ has exceeded 20 million, which leads to a reduction in grain yield of more than 10 million tons annually [5].

*e-mail: tianjinzhangyi@126.com
Thus it can be seen that heavy metal pollution of soil is not only a threat to the plate and soil organism but also a challenge to the survival of humanity itself. Many methods have been applied to soil remediation, such as reverse osmosis, membrane filtration, and the adsorption method $[6,7]$ - the most important physical-chemical method for its low cost, good effect, and high operability. There are a variety of adsorbing materials in soil remediation, which can be divided into three major categories:

a) inorganic minerals including clay, activated carbon zeolite, and molecular sieve

b) artificial synthetic materials, including polyvinyl resin and silicone resin

c) biomass materials, including lignin, chitosan, and protein

As one kind of biomass material, rabbit hair has very high protein content (about 93\%) and relatively low crystalline content (13.84-15.50\%) [8]. Rabbit hair is abundantly present in textile processing due to its poor spinnability [9]. All wastes are mostly disposed of in landfills, since burning them is inefficient and brings contamination 
because of the sulfur content of 3-4\% [10]. Meanwhile, the numerous amino and amide groups that exist on the rabbit natural protein macromolecule backbone and side chain can bind the heavy metal cations [11], thus making rabbit natural protein become a potential heavy metal ion adsorbent $[12,13]$. However, few studies have focused on the rabbit protein adsorption mechanism. Furthermore, little work has been done on preparing the newly heavy metal ion adsorbents with rabbit protein. Therefore, the aim of this study was to research the adsorption properties of copper (II) ions by rabbit protein. Due to the good adsorption and low cost of zeolite powder, it was firstly used to be the core of nano protein membrane, which was prepared by electrospinning to remediate the soil heavy metal ion pollution.

\section{Material and Methods}

The rabbit protein was prepared by reduction method C. Rabbit hair was cleaned, cut into small snippets, and then dissolved in an aqueous solution of urea, sodium bisulfite, and sodium dodecyl sulfate and heated to $85^{\circ} \mathrm{C}$ for $4 \mathrm{~h}$ in a water bath pot. Then dialysis and freeze drying were used to prepare the rabbit protein particle.

Nano Protein Membrane [14] was prepared by electrostatic spinning. Firstly, a zeolite wafer was mixed with the synthetic zeolite and ceramic clay at a ratio of $2.5: 2$, shaped by a homemade abrasive tool (thickness of $5 \mathrm{~mm}$, diameter of $27 \mathrm{~mm}$ ), and burned in a tube furnace at $1300^{\circ} \mathrm{C}$ for $6 \mathrm{~h}$. The zeolite wafer was prepared. Secondly, the electrospinning solution was prepared by dissolving the rabbit protein in polyethylene glycol 600, dripping two drops of waterborne polyurethane resin as film-former, and oscillating into the ultrasonic cleaners for $30 \mathrm{~min}$. The solution was prepared. Lastly, the zeolite wafer was fixed in the rotating stainless disk and the nano protein membrane was prepared by electrospinning with a voltage of $22 \mathrm{kv}$, flow rate 0.008 $\mathrm{ml} / \mathrm{min}$, and a trip to the target distance of $15 \mathrm{~cm}$. Then $50 \%$ glutaraldehyde was used to crosslink with steam for $4 \mathrm{~h}$. The nano protein membrane was prepared.

Fourier-transform infrared spectroscopy (FT-IR) of rabbit hair fibre and rabbit hair protein was performed in a NICOLET IS50 Fourier-transform spectrometer, at a resolution of $4 \mathrm{~cm}^{-1}$ over the wave number range of 4000 $400 \mathrm{~cm}^{-1}$ using the $\mathrm{KBr}$ pellet method.

The rabbit protein and nano protein membrane morphology were observed under S-4800 and TM-1000 field emission-scanning electron microscopes. Before SEM analysis, the samples were sputter coated with a gold layer by using an Emitech K550 sputter. The particle size was measured by particle size distribution software and tested 100 times. Then the average value was evaluated.

For the metal ions adsorption tests, standard solutions of $\mathrm{Cu}^{2+} 5,10,15,20,25$, and $30 \mathrm{mg} / \mathrm{ml}$ were prepared by dissolving an appropriate amount of pure copper in distilled water. Then, two heavy metal adsorbents were used in this study: pure rabbit protein and nano protein membrane. The UV2401PC ultraviolet-visible spectrophotometer was used to measure $\mathrm{Cu}^{2+}$ concentration at a wavelength of
$810 \mathrm{~nm}$, calibrated with the standard solutions of $\mathrm{Cu}^{2+} 5,10$, $15,20,25$, and $30 \mathrm{mg} / \mathrm{ml}$.

The adsorption capacity by the adsorbents was calculated using Eq. (1):

$$
Q=V\left(C_{0}-C\right) / W
$$

The percentage removal efficiency of $\mathrm{Cu}^{2+}$ was evaluated as Eq. (2):

$$
\text { Removal percentage }(\%)=\left(C_{0}-C\right) / C_{0} \times 100 \%
$$

...where $Q(\mathrm{mg} / \mathrm{g})$ is the adsorption capacity of the adsorbents at a given time; $V$ is the volume $(\mathrm{ml})$ of the $\mathrm{Cu}^{2+}$ solutions; $C_{0}$ and $C$ are the $\mathrm{Cu}^{2+}$ concentration $(\mathrm{mg} / \mathrm{ml})$ initially and at a given time, respectively; and $W$ is the mass (g) of the adsorbents.

To optimize the adsorption time, the rabbit protein, accurately weighing $5 \mathrm{~g}$, was bathed in $100 \mathrm{ml}$ copper sulfate solution and kept shaking for 20, 40, 60, 90, 120, 180, and $300 \mathrm{~min}$. Then the solution was collected in a centrifuge tube and centrifuged for two min in the centrifuge, and the supernatant fluid was determined to evaluate the concentration of $\mathrm{Cu}^{2+}$.

To optimize the adsorption dose quantity, the rabbit protein was accurately weighed at $0.5,1.0,1.5,2.5,5$, and $10 \mathrm{~g}$ and bathed in $100 \mathrm{ml}$ copper sulfate solution and kept shaking for $180 \mathrm{~min}$. Then the solution was collected in a centrifuge tube and centrifuged for two $\mathrm{min}$ in the centrifuge, and the supernatant fluid was determined to evaluate the concentration of $\mathrm{Cu}^{2+}$.

The nano protein membrane was accurately weighed at $0.05,0.1,0.2,0.5,1.0,3.0,5.0$, and $10 \mathrm{~g}$ and bathed in $100 \mathrm{ml}$ copper sulfate solution and kept shaking for $180 \mathrm{~min}$. Then the solution was collected in a centrifuge tube and centrifuged for two min in the centrifuge, and the supernatant fluid was determined to evaluate the concentration of $\mathrm{Cu}^{2+}$. In addition, to ensure the accuracy of the results all measurement and test were done in triplicate.

\section{Results and Discussion}

Rabbit protein and nano protein membrane characterization is reported in Fig. 1. Rabbit protein is shown in Fig. 1 (a). The average particle size of rabbit protein, which was prepared by reduction method C, was $177 \mathrm{~nm}$. And because of the freeze drying method, the rabbit protein particle was dispersed evenly. Nano protein membrane is shown in Fig. 1 (b). The rabbit protein was dispersed uniformly in the surface of zeolite. The strength and toughness of the nano protein membrane was excellent.

The infrared spectrum of rabbit hair fibre and rabbit hair protein extracted by reduction-C method are shown in Fig. 2 . It could be seen that both of them have the typical molecular structure that characterize absorption peaks of protein, including Amide I $(\mathrm{C}=\mathrm{O})$, Amide II $\left(-\mathrm{NH}_{2}\right)$, hydroxy, and carboxyl groups [15]. Compared with rabbit hair fibre, the 

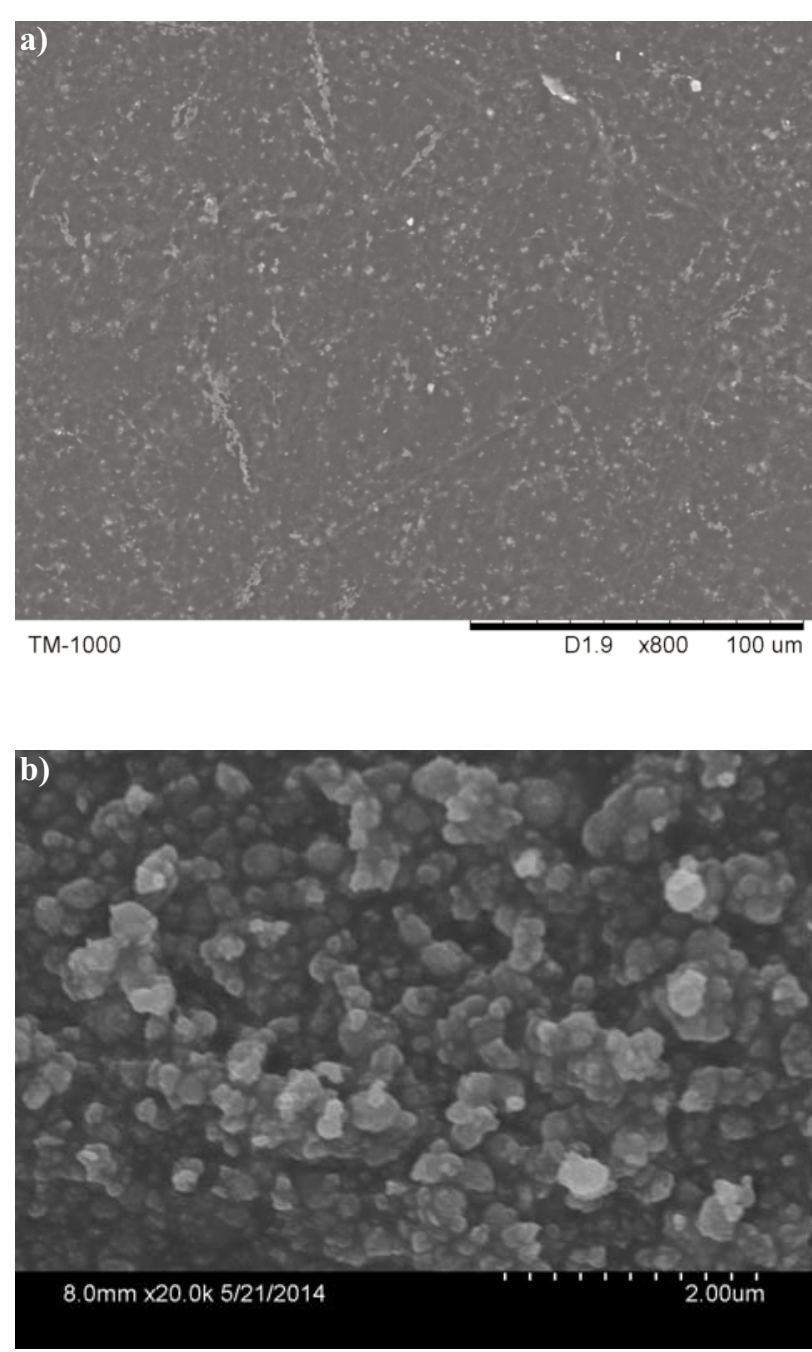

Fig. 1. The morphology characterization of (a) rabbit protein and (b) nano protein membrane.

absorption peak of Amide I in rabbit protein switched from $1,619 \mathrm{~cm}^{-1}$ to $1,657 \mathrm{~cm}^{-1}$, which indicated the molecular conformation of rabbit protein has changed from $\alpha$-helix to $\beta$-pleated sheet. This might because part of the $\alpha$-helical conformations were broken during the reduction reaction process and led to a decline of molecule chain alignment of rabbit protein. Meanwhile, the absorption peak of Amide II $\left(-\mathrm{NH}_{2}\right)$ in rabbit hair protein shifted from $1,451 \mathrm{~cm}^{-1}$ to $1,500 \mathrm{~cm}^{-1}$, which might be because along with the breakage of hydrogen bonds among the rabbit macromolecules, the cyclic structures of protein molecules were broken, which enhanced the polarity of the carbanyl group as a result of the absorption peak of $\mathrm{C}=\mathrm{O}$ moving to a high wave number [16].

The $\mathrm{Cu}^{2+}$ absorbability of rabbit protein is reported in Fig. 3. The standard curve of copper sulfate solution is shown in Fig. 3(a). The linearized equation was:

$$
\mathrm{Y}=0.04995 \times \mathrm{X}-0.0032, \mathrm{R}=0.9998
$$

The optimization of the rabbit protein adsorption time is shown in Fig. 3 (b). As adsorption time increased, adsorption efficiency increased. The adsorption rate was fast with- in $90 \mathrm{~min}$, but after $180 \mathrm{~min}$, with the increase of adsorption time, the increase of adsorption efficiency was not obvious and the percentage removal reached $58.52 \%$. Thus, the optimal rabbit protein adsorption time was $180 \mathrm{~min}$.

The optimization of the rabbit protein adsorption dosing quantity is shown in Fig. 3 (c). With the increase of adsorption dosing quantity, the percentage removal of $\mathrm{Cu}^{2+}$ increased. But after the dosing quantity of $50 \mathrm{~g} / \mathrm{l}$, as the dosing quantity increased, the adsorption quantity decreased. Hence, the optimal of the rabbit adsorption dosing quantity was $50 \mathrm{~g} / \mathrm{l}$ and the excellent adsorption of $\mathrm{Cu}^{2+}$ was verified.

For the further study of the rabbit protein adsorption properties of copper (II), the pseudo-first-order kinetic equation, quasi-secondary dynamic equation, and particle diffusion equation were used, respectively, to fit the adsorption tests data. The equation correlation coefficient, which was obtained from the model after linearization, was used to inspect the fitting results. Data processing was carried out with ORIGIN 7.0 software. As shown in Fig. 3 (d), the quasi-secondary dynamic equation had a good fitting regression effect more conducive to describing the process of rabbit protein adsorption of copper (II). The linearized equation was:
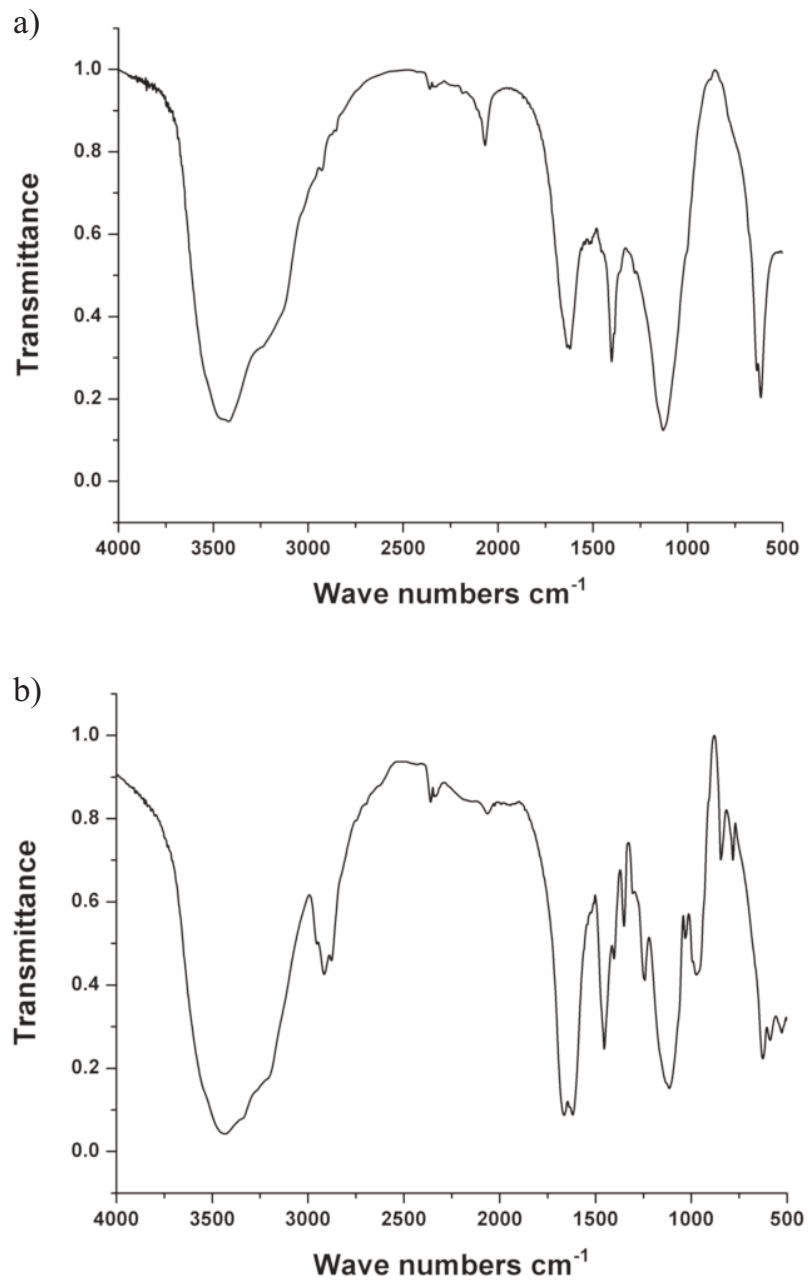

Fig. 2. Infrared spectrum of (a) rabbit hair fiber and (b) rabbit hair protein extracted by reduction-C method. 

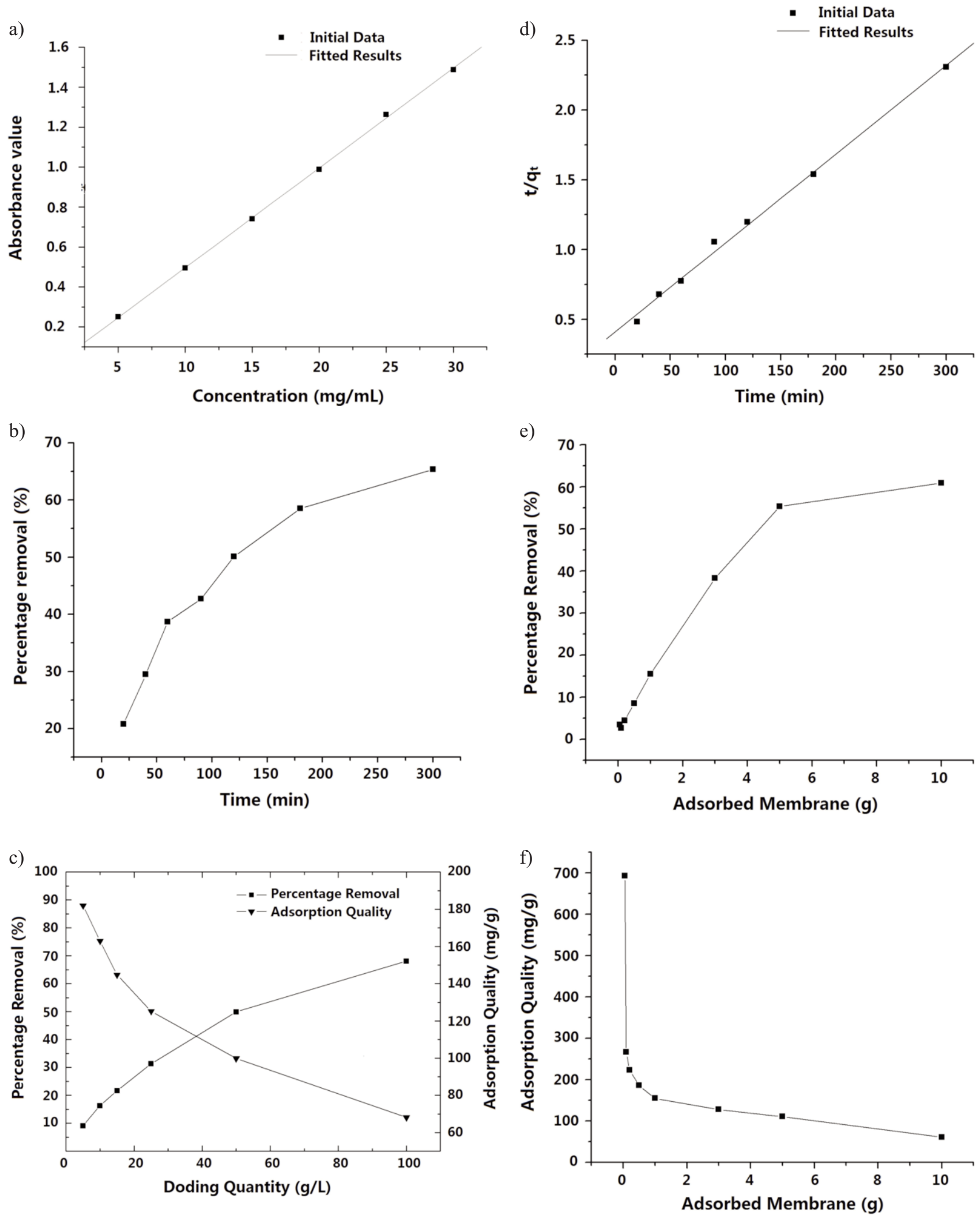

Fig. 3. The results of $\mathrm{Cu}^{2+}$ adsorption test.

(a) Standard curve of copper sulfate solution

(b) Optimization of the adsorption time results

(c) Optimization of the adsorption dosing quantity results

(d) Rabbit protein fitted results of the quasi secondary dynamic equation

(e) The percentage removal of the nano protein membrane

(f) The adsorption quantity of the nano protein membrane 


$$
\mathrm{Y}=0.40999+0.00637 \mathrm{x}, \mathrm{R}=0.99788
$$

...where $k_{2}=0.00022$ and $q_{e}=130.06$, according to the quasisecondary dynamic equation (Eq. 3):

$$
\frac{t}{q_{t}}=\frac{1}{k_{2} q_{e}^{2}}+\frac{t}{q_{e}}
$$

...where $q_{e}(\mathrm{mg} / \mathrm{g})$ is the balance adsorption capacity, $q_{t}(\mathrm{mg} / \mathrm{g})$ is the adsorption capacity at a given time, and $k_{2}$ $(\mathrm{g} / \mathrm{mg} \cdot \mathrm{min})$ is the quasi secondary adsorption rate constant.

The analysis showed that the adsorption process fit the quasi secondary dynamic equation, which meant the course of rabbit protein adsorbing heavy metal ion was a complex process including the surface diffusion intragranular diffusion process [17]. The surface diffusion included a combination of heavy metal ions and active groups such as carboxyl, amino, and hydroxy groups existing on the surface of adsorbent (passive adsorption); while the initiative adsorption was the diffusion, transmission and deposition of heavy metal ions were inside the adsorbent $[18,19]$. The quasi-secondary dynamic equation could be used to simulate the adsorption process of rabbit protein to $\mathrm{Cu}^{2+}$.

The adsorption property of nano protein membrane is shown in Figs. 3 (e) and (f). When the adsorption dosing quantity was $10 \mathrm{~g}$, the percentage removal of $\mathrm{Cu}^{2+}$ reached $60.9 \%$ and the adsorpion quantity was $60.9 \mathrm{mg} / \mathrm{g}$. Compared to the rabbit protein, if the adsorbent dosage were the same $5 \mathrm{~g}$, the percentage removal of $\mathrm{Cu}^{2+}$ was, respectively, $55.32 \%$ and $58.52 \%$. Although the result of the former was slightly lower than the latter, the content of rabbit protein was much lower than the latter because of the zeolite powder. So the cost of adsorbent material was greatly reduced, while maintaining the high percentage removal. Due to the high specific surface area and the numerous amino and amide groups, the nano protein membrane had great application potential in the adsorption industry and soil remediation.

\section{Conclusion}

In this work, the rabbit protein particle having a mean diameter of about $177 \mathrm{~nm}$ and the nano protein membrane were prepared by electrospinning. Morphology characterization of the rabbit protein showed that the average particle size of rabbit protein was $177 \mathrm{~nm}$ and dispersed evenly, and the nano protein membrane was dispersed uniformly in the surface of zeolite. The strength and toughness was excellent.

The adsorption tests showed that the optimal rabbit protein adsorption time and the dosing quantity was $180 \mathrm{~min}$ and $50 \mathrm{~g} / \mathrm{l}$, respectively. The percentage removal reached $58.52 \%$ and the excellent adsorption of $\mathrm{Cu}^{2+}$ was verified. The analysis of the rabbit protein adsorption mechanism showed that the quasi-secondary dynamic equation had a good fitting regression effect more conducive to describing the process of rabbit protein adsorption of copper (II).
The adsorption tests of nano protein membrane showed that when the adsorption dosing quantity was $10 \mathrm{~g}$, the percentage removal of $\mathrm{Cu}^{2+}$ reached $60.9 \%$ and the adsorption quantity was $60.9 \mathrm{mg} / \mathrm{g}$. The cost of adsorbent material was greatly reduced while maintaining the high percentage removal. The nano protein membrane had great application potential in the adsorption industry and soil remediation.

Using the waste of rabbit hair to treat the pollution of heavy metal ions in the soil not only realized the reasonable use of a natural protein resource, but also had a certain practical significance for the safety of green organic food.

\section{References}

1. EMMING G., HAUSCHILD M.Z., BJERG P.L. Life cycle assessment of soil and groundwater remediation technologies: literature review. Int. J. Life. Cycle. Ass., 15, 1, 2009.

2. EDWARD R.C., SELVAM G.S. Construction of green fluorescent protein based bacterialbiosensor. Int. J. Environ. Sci. Tech, 8, 793, 2011.

3. LI Z., ZHOU M.M., LIN W. The Research of Nanoparticle and Microparticle Hydroxyapatite Amendment in Multiple Heavy Metals Contaminated Soil Remediation. J. Nanomater., 17, 6238, 2014.

4. LIAO Y.P., MIN X.B., YANG Z.H., CHAI L.Y., ZHANG S.J. Physicochemical and biological quality of soil in hexavalent chromium-contaminated soils as affected by chemical and microbial remediation. Environ Sci Pollut R., 21, 379, 2014.

5. CHAO M.A., WANG T.W., LI J.K. Review on the Pollution-free, Green and Organic. Agr. Sci. Tech., 13, 1145, 2012.

6. CHEN F., XING J.H., CAO Z.W. Study on the Electrokinetic Remediation Technology of Cr (VI) Polluted Soil. Adv. Mater. Res., 726, 1751, 2013.

7. OTTOSEN L.M., LEPKOVA K., KUBAL M. Comparison of electrodialytic removal of $\mathrm{Cu}$ from spiked kaolinite, spiked soil and industrially polluted soil. J. Hazard Mater., 137, 113, 2006.

8. ZHENG Q.T., ZHANG M.X., LIU H.W. Morphological Structures of Rabbit Hair. Adv. Mater. Res., 332, 1063, 2011.

9. ALUIGI A., TONETTI C., VINEIS C. Adsorption of copper(II) ions by keratin/PA6 blend nanofibres [J]. Eur. Polym. J., 47, 1756, 2011.

10. ZOCCOLA M., ALUIGI A., PATRUCCO A. Microwaveassisted chemical-free hydrolysis of wool keratin. Text. Res. J., 82, 2006, 2012.

11. TATSUO M., YASUKI T., SHINANO T. Selective Adsorption and Recovery of Precious Metal Ions Using Protein-rich Biomass as Efficient Adsorbents. Process. Biochem., 49, 850, 2014.

12. PATIL K., SUZANNE V.S., RANGAM R., TAKUYA T., WANG X. G., LIN T. Milled cashmere guard hair powders: Absorption properties to heavy metal ions. Powder Technol., 218, 162, 2012.

13. CHEN C., WANG J.L. Relationship of Biosorption Capacity of Heavy Metal Ions by Saccharomyces Cerevisiae and Their Ionic Characteristics. Environ. Sci., 28, 1732, 2007.

14. ALUIGI A., ROMBALDONI F., TONETTI C., JANNOKE L. Study of Methylene Blue Adsorption on Kertain Nanofibrous Membranes. J. Hazard Mater., 268, 156, 2014. 
15. WU X., GONG F., WANG W. Protein extraction from plant tissues for 2DE and its application in proteomic analysis. Proteom., 14, 645, 2014.

16. HARIS P., SEVERCAN F. FTIR spectroscopic characterization of protein structure in aqueous and non-aqueous media. J. Mol. Catal. B-Enzym., 7, 207, 1999.

17. LIN C.X., ZHAN H.Y., LIU M.H. The Rmodynamics and Kinetics of Adsorption of $\mathrm{Cu}$ (II) from Aqueous Solutions onto a Spherical Cellulose. Ion. Exc. Adsorpt., 26, 226, 2010.
18. QI C., ZHU Y., CHEN F. Microwave hydrothermal transformation of amorphous calcium carbonate nanospheres and application in protein adsorption. ACS. Appl. Mater. Inter., 6, 4310, 2014

19. SCHLIPF D. M., RANKIN S. E., KNUTSON B L. Poresize dependent protein adsorption and protection from proteolytic hydrolysis in tailored mesoporous silica particles. ACS. Appl. Mater. Inter., 5, 10111, 2013. 